\title{
Pengetahuan Orangtua Mengenai Obat Puyer dī Poliklinik Umum Departemen IImu Kesehatan Anak FKUI-RSCM
}

\author{
Soepardi Soedibyo, Effee Koesnandar \\ Pediatri Rawat Jalan, Departemen Ilmu Kesehatan Anak FKUI/RSCM
}

\begin{abstract}
Latar belakang. Obat puyer telah lazim diterima oleh masyarakat, hal ini tidak terlepas dari kebiasaan dokter yang sering meresepkannya. Peresepan obat puyer mulai banyak dikritisi, bahkan menjadi topik menarik saat diseminarkan. Dalam era evidence based medicine (EBM) saat ini, peresepan obat puyer perlu dikaji kembali sehingga sesuai dengan kaidah praktik peresepan dan pembuatan obat yang baik.

Tujuan. Mengetahui bagaimana pengetahuan, sikap dan perilaku orangtua yang datang ke Poliklinik Umum Departemen Ilmu Kesehatan Anak FKUI-RSCM mengenai peresepan obat puyer.

Metode. Desain studi deskriptif cross sectional, pengambilan sampel secara konsekutif dilakukan selama bulan Juni 2008, dengan menggunakan kuesioner sederhana yang berisi 10 pertanyaan. Subjek penelitian adalah orangtua pasien yang datang pada periode penelitian dan bersedia mengisi kuesioner penelitian. Hasil. Dari 119 responden, 111 responden (93,3\%) diantaranya pernah mendapatkan obat puyer. Sebaran umur, pendidikan, dan pekerjaan responden, berturut-turut didapatkan responden berusia $>30-40$ tahun $(57,1 \%)$, pendidikan kategori sedang $(59,7 \%)$, dan mempunyai status bekerja $(65,5 \%)$. Sebaran responden lebih banyak pada umur anak antara 1-5 tahun (47,1\%), jumlah anak 1-3 orang $(85,0 \%)$, jumlah obat dalam satu puyer lebih dari satu macam (64,9\%), dan obat diperoleh di apotik (59,5\%). Responden yang tidak menyukai obat puyer $(58,6 \%)$, terutama responden, berturut-turut $(57,7 \%),(56,8 \%)$, dan $(62,2 \%)$ menyatakan harga obat, kemanjuran, dan ketepatan dosis obat puyer sama saja dengan obat sirup.

Kesimpulan. Hampir semua responden pernah mendapatkan obat puyer. Responden lebih banyak yang menyatakan tidak menyukai obat puyer, serta menilai harga, kemanjuran dan ketepatan dosis obat puyer sama saja dengan obat sirup. (Sari Pediatri 2009;10(6):397-403).
\end{abstract}

Kata kunci: pengetahuan, orangtua, obat puyer

\footnotetext{
Alamat Korespondensi:

Prof. Dr. Soepardi Soedibyo, SpA(K). Pediatri Rawat Jalan Dep. Ilmu Kesehatan Anak FKUI. Divisi Nutrisi dan metabolik. Departemen Ilmu Kesehatan Anak FKUI-RSCM. Jl. Salemba no.6, Jakarta 10430. Telepon: 021- 3915179. Fax: 021-390 7743.
}

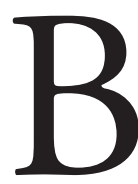
erobat adalah aktivitas yang pernah dilakukan hampir oleh semua orang selama hidupnya, tidak ada yang rela membiarkan diri sendiri atau keluarganya menderita sakit sehingga mereka akan segera mencari dokter untuk 
mengobati penyakitnya. Kepercayaan pasien yang sangat tinggi kepada dokter dan budaya paternalistik dalam masyarakat menyebabkan pasien menerima saja resep obat dari dokter tanpa banyak bertanya tentang berbagai aspek tentang obat tersebut kepada dokter. ${ }^{1}$ Dalam kurikulum pendidikan FKUI sampai saat ini masih diajarkan cara pembuatan puyer, dan ini terjadi sejak puluhan tahun yang lalu (oleh Departemen Farmasi) dan pengobatan yang rasional (oleh Departemen Farmakologi dan Departemen Klinik).

Obat racikan dalam bentuk puyer (obat puyer) yang diresepkan dokter telah lazim diterima masyarakat, bahkan sebagian berasumsi obat puyer lebih manjur dan lebih tepat untuk anak. Hal ini tidak terlepas dari peran dokter yang terbiasa memberikan obat puyer, dan keyakinan masyarakat bahwa setiap dokter punya obat racikan tersendiri yang merupakan campuran dari beberapa obat dengan dosis tertentu. Dalam dunia kedokteran sering disebutkan bahwa medicine is an art sehingga setiap dokter punya cara tersendiri dalam menegakkan diagnosis dan menentukan pengobatan. Pengamatan pada sebuah rumah sakit di Jakarta, didapatkan dari 130 resep obat untuk anak, dua pertiga dari resep merupakan obat puyer. ${ }^{2}$

Peresepan puyer saat ini mulai banyak dikritik, hal ini terkait dengan berkembangnya ilmu kedokteran dan cara pandang baru dalam dunia kedokteran. Dalam era EBM saat ini, setiap dokter dituntut untuk selalu memperbaharui pengetahuannya dalam dunia kedokteran, mendiagnosis pasien dan memberikan pengobatan berdasarkan bukti ilmiah terbaru. Badan Kesehatan Dunia (WHO) merekomendasikan banyak hal untuk keamanan dan keselamatan pasien, diantaranya merekomendasikan praktik peresepan yang baik dan pembuatan obat yang baik. ${ }^{3}$

Di Indonesia peresepan obat puyer masih diterima oleh masyarakat, dan pembuat resep puyer bukan monopoli dokter anak. Dokter umum maupun spesialis yang lain juga membuat puyer dalam bentuk puyer maupun dalam bentuk kapsul, namun keadaan ini mulai banyak disoroti, sehingga perlu dilakukan penelitian terkait pemberian obat puyer ini. Penelitian ini bertujuan untuk mengetahui bagaimana pengetahuan, sikap, dan perilaku masyarakat terhadap peresepan obat puyer oleh dokter.

\section{Metode}

Penelitian dilakukan di Poliklinik Umum Departemen Ilmu Kesehatan Anak FKUI-RSCM menggunakan desain studi deskriptif dengan metode cross sectional dan pengambilan subjek penelitian dilakukan secara konsekutif selama bulan Juni 2008. Kuesioner penelitian terdiri dari sepuluh pertanyaan yang terdiri dari satu pertanyaan pembuka yang menanyakan apakah responden pernah mendapat puyer atau tidak, dan dilanjutkan dengan sembilan pertanyaan berikutnya bila jawabannya ya. Subjek penelitian adalah orangtua pasien yang datang pada periode penelitian dan bersedia mengisi kuesioner penelitian yang telah disediakan, sebelum pengisian kuesioner diberikan penjelasan dan dimintakan persetujuan responden untuk mengikuti penelitian. Semua data yang diperoleh dimasukkan dan dianalisis ke dalam data base komputer menggunakan program SPSS versi 12.0. Hasil penelitian disajikan dalam bentuk tabel dan narasi.

\section{Hasil}

Karakteristik responden mencakup jenis kelamin, usia, pendidikan, pekerjaan, usia anak, jumlah anak serta jumlah tangggungan responden. Sebaran responden dibagi menurut jawaban terhadap pertanyaan yang diberikan, mencakup gejala penyakit dan indikasi pemberian obat puyer, isi dan jumlah obat yang terkandung dalam satu puyer, penjelasan dokter saat memberikan obat puyer, kecenderungan pemilihan terhadap obat puyer, pendapat mengenai harga, kemanjuran, dan ketepatan dosis obat puyer. Hasil penelitian menurut karakteristik responden disajikan dalam bentuk tabel (Tabel 1).

Responden pada penelitian ini berjumlah 119 orang, terdiri dari 48 responden laki-laki $(40,3 \%)$ dan 71 responden perempuan $(59,7 \%)$. Sebaran usia responden lebih banyak antara usia $>30-40$ tahun 68 responden $(57,1 \%)$, usia $20-30$ tahun 30 responden $(25,2 \%)$ dan yang berusia $>40$ tahun 21 orang $(17,7 \%)$. Sebaran tingkat pendidikan responden kategori sedang, terbanyak 71 responden $(59,7 \%)$, sedangkan kategori pendidikan tinggi 31 responden $(26,0 \%)$, dan pendidikan rendah 17 responden $(14,3 \%)$. Pada sebaran responden menurut pekerjaan, didapatkan responden yang bekerja 78 responden 
$(65,5 \%)$, lebih banyak dibandingkan responden yang tidak bekerja yaitu 41 responden $(34,5 \%)$. Sebaran usia anak responden kebanyakan anak berusia antara

Tabel 1. Karakteristik responden

\begin{tabular}{|c|c|c|}
\hline Variabel & $\begin{array}{c}\text { Frekuensi } \\
(\mathrm{n}=119)\end{array}$ & $\begin{array}{c}\text { Persentase } \\
(\%)\end{array}$ \\
\hline \multicolumn{3}{|l|}{ Jenis Kelamin } \\
\hline Laki-laki & 48 & 40,3 \\
\hline Perempuan & 71 & 59,7 \\
\hline \multicolumn{3}{|l|}{ Usia (tahun) } \\
\hline $20-30$ & 30 & 25,2 \\
\hline$>30-40$ & 68 & 57,1 \\
\hline$>40$ & 21 & 17,7 \\
\hline \multicolumn{3}{|l|}{ Pendidikan } \\
\hline Tinggi & 31 & 26,0 \\
\hline Sedang & 71 & 59,7 \\
\hline Rendah & 17 & 14,3 \\
\hline \multicolumn{3}{|l|}{ Pekerjaan } \\
\hline Bekerja & 78 & 65,5 \\
\hline Tidak bekerja & 41 & 34,5 \\
\hline \multicolumn{3}{|l|}{ Umur anak (tahun) } \\
\hline$<1$ & 19 & 15,9 \\
\hline $1-5$ & 56 & 47,1 \\
\hline$>5$ & 43 & 36,0 \\
\hline \multicolumn{3}{|l|}{ Jumlah anak (orang) } \\
\hline $1-3$ & 101 & 85 \\
\hline $4-5$ & 12 & 10 \\
\hline$>5$ & 6 & 5 \\
\hline \multicolumn{3}{|c|}{ Riwayat pemberian obat puyer } \\
\hline Ya, pernah & 111 & 93,3 \\
\hline Tidak pernah & 8 & 6,7 \\
\hline
\end{tabular}

$1-5$ tahun 56 responden $(47,1 \%)$, yang mempunyai anak berusia $>5$ tahun 43 responden (36\%), dan anak berusia $<1$ tahun 16 responden (15,9\%). Sebaran responden menurut jumlah anak didapatkan 101 responden $(85,0 \%)$ mempunyai $1-3$ orang anak, mempunyai anak $4-5$ orang 12 responden $(10,0 \%)$, dan anak $>5$ orang hanya 6 responden $(5,0 \%)$. Dari 119 responden yang mengisi kuesioner, sebagian besar responden 111 responden (93,3\%) menyatakan pernah mendapatkan obat puyer, sedangkan yang menyatakan tidak pernah mendapat obat puyer hanya 8 responden $(6,7 \%)$, sehingga jumlah responden yang mengisi seluruh kuesioner berjumlah 111 responden. Obat puyer sering diberikan untuk mengobati gejala klinis (simptomatis), terkadang dalam satu puyer mengandung beberapa macam obat yang ditujukan untuk mengurangi beberapa keluhan klinis. Semakin banyak gejala klinis yang dikeluhkan pasien semakin banyak pula jumlah obat yang terkandung dalam satu puyer. Sebaran responden menurut gejala penyakit saat mendapat obat puyer, isi obat puyer dan jumlah obat yang terkandung dalam satu puyer disajikan pada Tabel 2.

Gejala penyakit yang menyebabkan responden membawa anaknya berobat ke dokter dan mendapatkan obat puyer, paling banyak dengan keluhan batuk pilek 68 responden $(61,3 \%)$, keluhan demam 30 responden $(27,0 \%)$, keluhan diare pada 7 responden $(6,3 \%)$, dan keluhan lain 6 responden $(5,4 \%)$. Sebagian besar responden mengetahui isi obat puyer yang diberikan dokter, responden menyatakan kebanyakan dokter memberikan obat puyer untuk

Tabel 2. Sebaran responden menurut gejala penyakit, isi dan jumlah obat dalam satu puyer

\begin{tabular}{lcc}
\hline Variabel & Frekuensi $(\mathrm{n}=111)$ & Persentase $(\%)$ \\
\hline Gejala penyakit saat dapat obat puyer & 7 & 6,3 \\
Diare & 68 & 61,3 \\
Batuk pilek & 30 & 27,0 \\
Demam & 6 & 5,4 \\
Lain-lain & & \\
Isi obat puyer & 3 & 2,7 \\
Puyer diare & 52 & 46,8 \\
Puyer batuk pilek & 16 & 14,4 \\
Puyer demam & 21 & 18,9 \\
Puyer antibiotik & 19 & 17,2 \\
Tidak tahu & & 7,2 \\
Jumlah obat dalam satu puyer & 8 & 64,9 \\
1 macam obat & 72 & 27,9 \\
Lebih dari 1 macam obat & 31 & \\
Tidak tahu & & \\
\hline
\end{tabular}


keluhan batuk pilek 52 responden $(46,8), 21$ responden $(18,9 \%)$ mendapatkan obat puyer antibiotik, obat puyer untuk demam disebutkan oleh 16 responden $(14,4 \%)$, dan puyer untuk diare 3 responden (2,7\%), sedangkan jumlah responden yang tidak mengetahui isi obat puyer yang diberikan 19 responden (17,2\%). Sebagian besar puyer yang diberikan pada responden mengandung lebih dari satu macam obat, seperti dinyatakan oleh 72 responden $(64,9 \%)$, sedangkan yang tidak mengetahui isi obat puyer $31(27,9 \%)$, dan yang menyebutkan satu macam obat dalam satu puyer $8(7,2 \%)$. Pembuatan obat racikan puyer merupakan tugas ahli farmasi, pasien akan membawa resep dari dokter ke apotek, walaupun saat ini sebagian kecil dokter dan klinik masih menyediakan dan menyiapkan sendiri obat yang diperlukan untuk pasiennya. Pada Tabel 3 tertera tempat responden memperoleh puyer.

Responden lebih banyak memperoleh obat puyer di apotek yaitu 66 responden (59,5\%) dibandingkan dengan yang memperoleh obat puyer di klinik atau praktek dokter, 45 responden $(40,5 \%)$. Salah satu pedoman dalam peresepan obat yang baik adalah pemberian informasi dari dokter kepada pasien tentang

Tabel 3. Sebaran responden menurut tempat memperoleh obat puyer

\begin{tabular}{lcc}
\hline Tempat memperoleh obat puyer & $\begin{array}{c}\text { Frekuensi } \\
(\mathrm{n}=111)\end{array}$ & $\%$ \\
\hline Praktek dokter/klinik & 45 & 40,5 \\
Apotek & 66 & 59,5 \\
\hline
\end{tabular}

Tabel 4. Sebaran responden menurut alasan dokter memberikan obat puyer

\begin{tabular}{lcc}
\hline $\begin{array}{l}\text { Dokter memberikan } \\
\text { penjelasan }\end{array}$ & $\begin{array}{c}\text { Frekuensi } \\
(\mathrm{n}=111)\end{array}$ & $\begin{array}{c}\text { Persentase } \\
(\%)\end{array}$ \\
\hline Ya & 52 & 46,8 \\
Tidak & 59 & 53,2 \\
\hline
\end{tabular}

Tabel 5. Sebaran responden menurut alasan memilih obat puyer

\begin{tabular}{lcc}
\hline Alasan memilih obat puyer & Frekuensi & Persentase \\
\hline Lebih menyukai obat puyer & 46 & 41,4 \\
Tidak menyukai obat puyer & 65 & 58,6 \\
\hline
\end{tabular}

obat yang diberikan termasuk alasan memberikan obat puyer. Sebaran responden menurut alasan dokter memberikan obat puyer tertera pada Tabel 4 .

Responden yang tidak mendapatkan penjelasan tentang alasan memberikan obat puyer dari dokter lebih banyak, 59 responden $(53,2 \%)$ dibandingkan responden yang mendapatkan penjelasan dari dokter 52 responden $(46,8 \%)$. Peresepan obat puyer di Indonesia sudah berlangsung lama dan masyarakat sudah terbiasa dengan obat puyer sehingga sudah bisa menyatakan sikapnya terhadap puyer seperti tertera pada Tabel 5.

Pada Tabel 5 tertera jumlah responden yang tidak menyukai obat puyer lebih banyak, 65 responden $(58,6 \%)$ dibandingkan yang menyukai obat puyer, 46 responden $(41,4 \%)$. Harga obat merupakan salah satu yang harus dipertimbangkan dokter dalam memberikan obat kepada pasien. Selama ini diasumsikan bahwa harga obat puyer lebih murah dibandingkan obat sirup. Pertimbangan lain adalah efikasi obat sesuai dengan penyakitnya, berdasarkan pilihan obat yang tepat, dosis yang tepat, dan formula yang tepat. Kemudahan anak dalam minum obat juga perlu diperhatikan, berikut ini dapat dilihat sebaran pendapat responden menurut kemanjuran dan ketepatan dosis obat puyer dibandingkan obat sirup.

Pada Tabel 7 didapatkan bahwa responden lebih banyak menyatakan harga obat puyer sama saja dengan harga obat sirup, 64 responden $(57,7 \%)$ sedangkan 30 responden $(27,0 \%)$ menyatakan obat puyer lebih murah dibandingkan obat sirup, dan 17 responden $(15,3 \%)$ menyatakan obat puyer lebih mahal dibandingkan obat sirup.

Responden yang menyatakan obat puyer sama saja kemanjurannya dibandingkan dengan obat sirup 63 responden (56,8\%), lebih banyak dibandingkan yang menyatakan obat puyer lebih manjur 40 (36\%), dan 8 menyatakan obat puyer tidak lebih manjur dibandingkan obat sirup.

Dosis obat mempengaruhi keberhasilan terapi, risiko efek samping, dan toksisitas. Bila yang diberikan adalah antibiotik maka hal ini juga berkaitan dengan risiko resistensi. Pada Tabel 7 tertera menurut sebagian besar responden ketepatan dosis obat puyer sama saja dengan obat sirup, 69 responden $(62,2 \%)$ sedangkan 37 responden $(33,3 \%)$ menyatakan dosis obat puyer lebih tepat dibandingkan obat sirup, dan 5 responden $(4,5 \%)$ menyatakan dosis obat puyer tidak lebih tepat dibandingkan obat sirup. 
Tabel 7. Sebaran responden menurut harga obat puyer dibandingkan sirup

\begin{tabular}{lcc}
\hline \multicolumn{1}{c}{ Obat puyer } & Frekuensi $(\mathrm{n}=111)$ & $\%$ \\
\hline Harga obat puyer & & \\
Lebih murah & 30 & 27,0 \\
Tidak lebih murah & 17 & 15,3 \\
$\quad$ Sama saja dengan sirup & 64 & 57,7 \\
Kemanjuran obat puyer & & \\
Lebih manjur & 40 & 36,0 \\
Tidak lebih manjur & 8 & 7,2 \\
Sama saja dengan sirup & 63 & 56.8 \\
Ketepatan dosis obat puyer & & \\
$\quad$ Lebih tepat & 37 & 33,3 \\
Tidak lebih tepat & 5 & 4,5 \\
Sama saja dengan sirup & 69 & 62,2 \\
\hline
\end{tabular}

\section{Pembahasan}

Dari penelitian yang kami lakukan didapatkan sebagian besar responden $(93,3 \%)$ pernah menerima resep obat puyer, hanya 8 orang responden $(6,7 \%)$ yang tidak pernah mendapat resep obat puyer. Kenyataan ini menunjukkan budaya peresepan obat puyer oleh dokter masih cukup tinggi walaupun hal ini mulai disoroti para ahli kesehatan dan banyak diperbincangkan masyarakat, terutama masyarakat yang terbiasa mengakses informasi melalui internet.

Usia responden terutama usia produktif $>30-40$ tahun yaitu 68 responden $(57,1 \%)$, yang bekerja lebih banyak 78 orang responden $(65,5 \%)$ dengan tingkat pendidikan rata-rata tamat SMA atau masuk dalam kategori sedang, 71 responden (59,7\%). Berdasarkan usia responden, tingkat pendidikan dan pekerjaan tampak bahwa kecakapan responden dalam menjawab kuesioner dapat dipertanggungjawabkan.

Sebaran usia anak responden kebanyakan anak berusia antara 1-5 tahun yaitu 56 responden $(47,1 \%)$, dan yang mempunyai anak berusia $<1$ tahun 16 responden (15,9\%). Jumlah anak responden kebanyakan antara 1-3 orang, $(85,0 \%)$. Sebagian besar responden mempunyai anak usia balita, usia yang masih mungkin mendapatkan resep obat puyer bila berobat dan melihat dari jumlah anak kebanyakan antara 1-3 anak, memungkinkan responden sudah mendapatkan obat puyer sebelumnya.

Gejala penyakit yang menyebabkan responden mendapatkan obat puyer paling banyak adalah keluhan batuk pilek $(61,3 \%)$, demam $(27,0 \%)$, diare
$(6,3 \%)$, dan keluhan lain $(5,4 \%)$. Pada penelitian yang dilakukan oleh Yayasan Orangtua Peduli (YOP) melalui pengumpulan resep obat yang diterima dan dikirim ke milis YOP, didapatkan kebanyakan resep puyer $87,0 \%$ untuk keluhan batuk, 72,6\% keluhan demam dan 55,4\% diare akut. Hasil dari penelitian ini menunjukkan hasil yang sama dengan penelitian YOP, peresepan obat puyer yang paling banyak adalah untuk keluhan batuk pilek, dan masih ada responden yang mendapatkan obat puyer untuk keluhan diare.

Sebagian besar responden mengetahui isi obat puyer yang diberikan dokter, sebagian besar dokter memberikan obat puyer batuk pilek (46,8\%), 18,9\% mendapatkan obat puyer antibiotik, obat puyer demam 16 responden $(14,4 \%)$, dan puyer diare sebanyak $2,7 \%$, sedangkan jumlah responden yang tidak mengetahui isi obat puyer 19 responden (17,2\%). Sebagian besar puyer yang diberikan pada responden mengandung lebih dari satu macam obat $(64,9 \%)$, sedangkan responden yang tidak mengetahui $27,9 \%$, dan yang menyebutkan satu macam obat dalam satu puyer $7,2 \%$. Penjelasan oleh dokter kepada responden mengenai obat yang diberikan bertujuan agar responden mengerti tujuan pengobatan, memahami cara minum atau cara pakai dan mewaspadai kemungkinan efek samping yang mungkin muncul. Sebagian besar responden pada penelitian ini mengetahui isi dan kandungan obat puyer yang diberikan.

Peraturan pemerintah menegaskan yang berwenang melakukan tugas kefarmasian adalah apoteker atau asisten apoteker dibawah pengawasan apoteker. Resep obat yang diberikan dokter harus diserahkan kepada ahli farmasi untuk diproses menjadi obat yang siap dikonsumsi. Pada penelitian kami didapatkan sebagian besar responden memperoleh obat puyer di apotek yaitu 66 responden $(59,5 \%)$ dan 45 responden (40,5\%) memperoleh obat puyer di klinik atau praktek dokter. Berdasarkan hasil penelitian ini perlu diamati lebih lanjut mengenai pembuatan resep di klinik dan praktek dokter, apakah sudah sesuai dengan ketentuan pembuatan obat yang baik.

Penjelasan mengenai obat yang diberikan oleh dokter merupakan salah satu dari komponen peresepan obat yang baik, namun pada penelitian kami terlihat jumlah responden yang tidak mendapatkan penjelasan tentang alasan memberikan obat puyer dari dokter masih lebih banyak 59 responden $(53,2 \%)$ dibandingkan responden yang mendapatkan penjelasan dari dokter 52 responden $(46,8 \%)$. 
Diharapkan para dokter senantiasa memberikan penjelasan dan masyarakat sebaiknya juga proaktif untuk menanyakan berbagai aspek dari obat yang diterimanya dari dokter.

Penulis tidak menemukan penelitan lain mengenai alasan responden menyukai obat puyer, namun asumsi yang beredar dalam masyarakat menyebutkan bahwa sebagian masyarakat fanatik dengan obat puyer. Namun pada penelitian kami terlihat bahwa jumlah responden yang tidak menyukai obat puyer justru lebih banyak yaitu 65 responden $(58,6 \%)$ dibandingkan jumlah responden yang menyukai obat puyer 46 responden $(41,4 \%)$. Asumsi bahwa masyarakat lebih menginginkan obat puyer dibandingkan obat sirup tidak terbukti pada penelitian kami.

Asumsi lain mengenai obat puyer adalah mengenai harga obat. Diasumsikan oleh kelompok masyarakat yang mendukung obat puyer bahwa harga obat puyer lebih murah, walaupun pada kelompok masyarakat yang tidak menyetujui mengatakan harga obat puyer tidak lebih murah karena proses pembuatannya membutuhkan waktu lebih lama sehingga menambah jam kerja petugas. Pada penelitian kami ternyata sebagian besar responden menyatakan harga obat puyer sama saja dengan harga obat sirup 64 responden $(57,7 \%)$, sedangkan 30 responden $(27,0 \%)$ menyatakan harga obat puyer lebih murah dibandingkan obat sirup, dan 17 responden (15,3\%) menyatakan harga obat puyer lebih mahal dibandingkan obat sirup. Berdasarkan hasil penelitian kami mengenai harga obat puyer dibandingkan obat sirup tampaknya tidak terlalu dirasakan berbeda oleh responden.

Efikasi obat merupakan salah satu pertimbangan dokter dalam memilih obat bagi pasiennya. Pertimbangan memilih obat puyer oleh dokter yang mendukungnya adalah sisi praktis pemberian obat dalam satu kemasan untuk beberapa gejala. Masyarakat sebagian berasumsi obat puyer lebih manjur karena jenis dan dosis obat disesuaikan dengan penyakit anak, dan dikemas dalam bentuk satu puyer.

Sebagian besar responden pada penelitian ini menyatakan obat puyer sama saja manjur dengan obat sirup yaitu 63 responden $(56,8 \%)$, sedangkan yang menyatakan obat puyer lebih manjur 40 responden (36\%), dan 8 responden menyatakan obat puyer tidak lebih manjur dibandingkan obat sirup. Hasil penelitian kami menunjukkan bahwa kemanjuran obat puyer dirasakan tidak jauh berbeda bila dibandingkan dengan obat sirup.
Ketepatan dosis obat puyer perlu dipertanyakan karena proses pembuatannya menyebabkan sebagian obat tertinggal pada wadah yang digunakan untuk menggerus obat, juga pada kertas pembungkus, terutama untuk obat dosis kecil. Dapat diketahui bahwa menurut sebagian besar responden ketepatan dosis obat puyer sama saja dengan obat sirup, yaitu sebanyak 69 responden $(62,2 \%)$, sedangkan sebanyak 37 responden $(33,3 \%)$ menyatakan dosis obat puyer lebih tepat dibandingkan obat sirup, dan 5 responden $(4,5 \%)$ menyatakan dosis obat puyer tidak lebih tepat dibandingkan obat sirup. Tampak responden tidak terlalu memahami kemungkinan adanya ketidaktepatan dosis obat puyer dibandingkan obat sirup.

\section{Kesimpulan}

Keluhan yang paling sering diobati dengan obat puyer oleh dokter adalah gejala batuk pilek, dengan kandungan jumlah obat dalam satu puyer lebih dari satu macam obat. Obat puyer lebih banyak diperoleh responden di apotik $(59,5 \%)$ dibandingkan obat puyer yang diperoleh di klinik atau praktek dokter. Responden yang tidak menyukai obat puyer, lebih banyak dibandingkan responden yang menyukai obat sirup. Harga obat menurut kebanyakan responden sama saja dengan obat sirup, kemanjuran obat puyer menurut kebanyakan responden juga sama saja dengan obat sirup, begitu juga mengenai ketepatan dosis obat puyer menurut responden sama saja obat puyer maupun obat sirup.

\section{Daftar Pustaka}

1. Pujiarto PS. Rationale use of medicine (RUM). Disampaikan pada seminar meet the expert: puyer, quo vadis? Jakarta, 3 Mei 2008.

2. Hafidz I. Puyer, quo vadis? Disampaikan pada seminar meet the expert: puyer, quo vadis? Jakarta 3 Mei 2008.

3. Setiabudy R. Praktik peresepan yang baik. Disampaikan pada seminar Meet the expert: Puyer, quo vadis? Jakarta, 3 Mei 2008.

4. Grahame-Smith DG, Aronson JK. Principles of prescribing. Dalam: Clinical pharmacology and drug therapy. Edisi ke-3. Oxford University Press; 2002.h. 173-80. 
5. Ross DD, Laing RO, Quick JD, Santoso B, Bimo, Chowdlury AK, dkk. Field tests for rational drug use in twelve developing countries. Lancet 1993;342:1408-10

6. Dawes M. Is this therapy effective? Dalam: Dawes M, Davies PT, Gray AM, Mant J, Seers K, Snowball R, penyunting. Evidence-based practise. Edinburg: Churchill Livingstone; 1999. h. 159-80.

7. Lofholm PW, Katzung B. Rational prescribing and prescription writing. Dalam: Katzung B, penyunting. Basic and clinical parmacology. Boston: Mc Graw-Hill; 2007. h. 1063-72.

8. World Health Organization. The role of education in the rational use of drugs. South East Asia regional office publication series, No.45, 2006:ix.

9. Arustiyono. Promoting Rational use of drugs at the community health centers in Indonesia. PhD Thesis, Department of International Health School Of Public
Health Boston University September 1999.

10. Bjerrum L. Pharmacoepidemiological studies of polypharmacy: methodological issues, population estimates, an influence of practice patterns. PhD Thesis, Research unit of general practice and Department Of Clinical Pharmacology The Faculty Of Health Sciences Odense University Denmark 1998.

11. Dwiprahasto I. Improving the quality of prescribing at primary health centres through a training intervention for doctors and paramedics. J Manajemen Pel Kes 2006: 94-101.

12. WHO. Quality assurance of pharmaceuticals. A compendium of guidelines and related materials. Vol 2, 2nd updated edition. Good manufacturing practices and inspection. Diunduh dari www.who.int/ topics/pharmaceutical_products/en. Diakses tanggal $30 \mathrm{Mei}$ 2008. 